\title{
A comparison of performance enhancing synergy among ultrafiltered yeast extracts and recombinant human serum albumin in $\mathrm{CHO}-\mathrm{K} 1$ cells
}

\author{
James F Babcock*, Karen A Benedict, Amanda L Perlman \\ From 22nd European Society for Animal Cell Technology (ESACT) Meeting on Cell Based Technologies \\ Vienna, Austria. 15-18 May 2011
}

\begin{abstract}
Introduction
We have previously demonstrated a synergistic reaction between a wheat hydrolysate and recombinant human serum albumin used to supplement a chemically defined growth medium for SP2/0 hybridoma cells. The data presented here illustrate the synergystic performance enhancing effect obtained when ultrafiltered yeast extract and recombinant human serum albumin are cosupplemented in $\mathrm{CHO}$ cell media. Each combination has its own distinctive effect on the growth and productivity of transfected cells. Cell viability, cell proliferation and target protein production all may be improved, yet these effects are not necessarily observed concurrently in a given system.
\end{abstract}

\section{Materials and methods}

Data were collected using a transfected CHO-K1 line, adapted to serum-free suspension culture, and engineered to constitutively express secreted embryonic alkaline phosphatase (SEAP) by means of a modified human cytomegalovirus (hCMV) promoter.

Cultures were grown in $125 \mathrm{ml}$ shake-flasks containing a final medium volume of $35 \mathrm{ml}$. The basal medium consisted of $100 \%$ chemically defined medium (CDM) supplemented with $1 \mathrm{mg} / \mathrm{ml}$ G-418. Triplicate flasks were seeded at $4.0 \times 10^{5}$ cells $/ \mathrm{ml}$, and incubated at $37^{\circ} \mathrm{C}$ in $5 \% \mathrm{CO}_{2}$ at $130 \mathrm{rpm}$ for 12 days. Medium supplement stock solutions were prepared at $100 \mathrm{~g} / \mathrm{l}$ in the basal medium and sterilized through a $2.0 \mu \mathrm{m}$ filter.

At days 5, 7, 8, 9 and 12, $1.0 \mathrm{ml}$ of the culture supernatants were removed for assessing cell counts and viability. Cells were counted using a Nova BioProfile Flex

\footnotetext{
* Correspondence: james.babcock@kerry.com
Sheffield Center for Cell Culture Technology, Sheffield Bio-Science, A Kerry

* Correspondence: james.babcock@kerry.com
Sheffield Center for Cell Culture Technology, Sheffield Bio-Science, A Kerry Group Business, Ithaca, NY USA
}

(c) 2011 Babcock et al; licensee BioMed Central Ltd. This is an open access article distributed under the terms of the Creative Commons Attribution License (http://creativecommons.org/licenses/by/2.0), which permits unrestricted use, distribution, and reproduction in any medium, provided the original work is properly cited.

\section{Summary}

The data presented here illustrate the performanceenhancing synergy that may be realized by supplementing various cell culture media with a combination of yeast extract and recombinant human serum albumin. When the two supplements are used together, cell culture performance results exceed those achieved when using each supplement individually. Overall performance was further improved by varying the individual dosages of yeast extract and recombinant human serum albumin. In four separate basal media, cell response to co-supplementation for each of the yeast extract/recombinant albumin combinations tested was shown to be both 

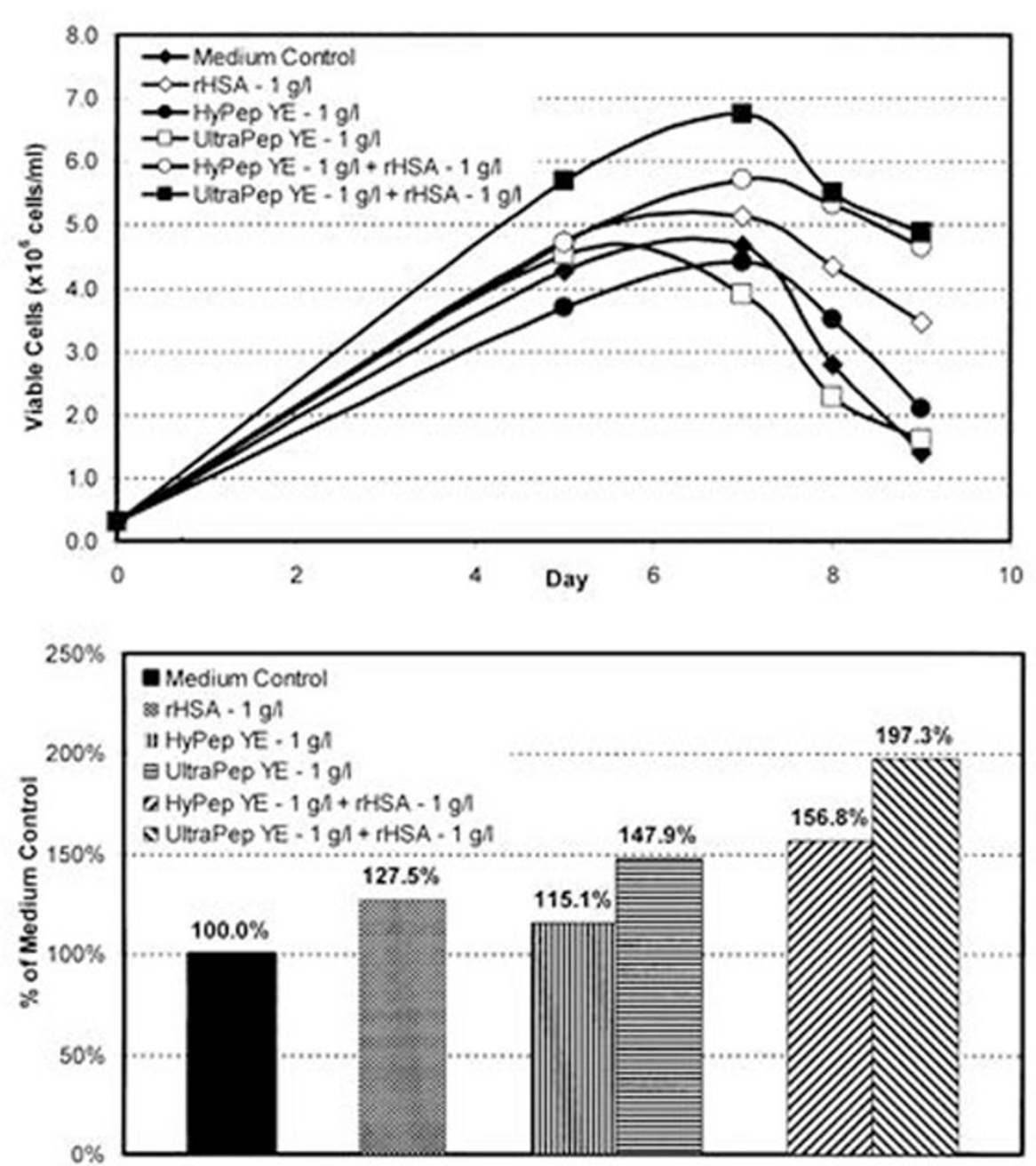

Figure 1 Growth Curves and SEAP Titers for rHSA, HyPep YE and UltraPep YE Supplemented Batch Cell Cultures

medium and dosage dependent. The optimized combination provided significant overall performance improvement in all media tested.

Published: 22 November 2011

doi:10.1186/1753-6561-5-S8-P26

Cite this article as: Babcock et al:: A comparison of performance enhancing synergy among ultrafiltered yeast extracts and recombinant

human serum albumin in CHO-K1 cells. BMC Proceedings 2011 5(Suppl 8): P26.
Submit your next manuscript to BioMed Central and take full advantage of:

- Convenient online submission

- Thorough peer review

- No space constraints or color figure charges

- Immediate publication on acceptance

- Inclusion in PubMed, CAS, Scopus and Google Scholar

- Research which is freely available for redistribution 